\title{
The Effect of Behavior and Characteristics of the Principal's Duty on the Satisfaction of Educators and Education at SMA Negeri Mesuji Makmur
}

\author{
Huzaini $^{1 *)}$, Bukman Lian ${ }^{1}$, Mulyadi ${ }^{1}$
}

\author{
${ }^{1}$ Universitas PGRI Palembang \\ *Corresponding author. Email: huzainihuzaini.hh@gmail.com,
}

\begin{abstract}
This research aimed to determine the influence of the behavior and characteristics of the principal's duties on the satisfaction of teachers and education staff at SMA Negeri Mesuji Makmur. The population and sample in this study were teachers of SMA Negeri Mesuji Makmur, totaling 56 respondents. The research method used is a descriptive quantitative research using a questionnaire. Data analysis in this study used simple and multiple linear regression through the SPSS version 25 for the windows program. The research and data analysis results show that the behavior of the principal has a very strong effect on the satisfaction of teachers and education. The magnitude of this influence is $87.7 \%$. The characteristics of the principal's duties have a very strong influence on teachers and education staff's satisfaction. The magnitude of this influence is $87.7 \%$. The behavior and characteristics of the principal's duties simultaneously have a very strong effect on the satisfaction of teachers and education staff at Mesuji Makmur State High School. The magnitude of this influence is $83.3 \%$.
\end{abstract}

Keywords: Principal Behavior, Principal Duties Characteristics, Teacher Satisfaction and Education.

\section{INTRODUCTION}

Education plays a vital role in ensuring the survival of the state and nation, because education is a vehicle for improving and developing human resources quality. With the pace of development, Indonesian society is still facing serious educational problems, especially those related to the quality, relevance, and efficiency of education. Education is the most important element in educating the nation's life. No nation or country can progress without first advancing the world of education. The progress of the world of education will positively impact efforts to increase human resources [1].

Efforts to build the quality of education continue. Both by the government and schools as education providers. In an attempt to meet society's needs and demands for the quality of education and as a response to the very rapid changes in life in the era of globalization. The aim is that the quality of education graduates can meet job needs and provide welfare for their families and communities. So that service to customer satisfaction becomes the main focus of school management. In the context of education, schools are seen as organizations that provide educational services to students and the community. Many factors support the satisfaction of teachers and education personnel, such as the behavior and characteristics of the principal's duties [2].

Leadership is an object and subject that has been studied, analyzed, and reflected by people from past to present [2]. The term leadership comes from the word leader which, according to The Oxford English Dictionary in [3] which was only used in 1300, while leadership did not appear until the mid17 th century in either political writing or the control of the British parliament. Leadership can occur when there is a leader who influences his followers. Leader is one of the essential elements of leadership, without a leader there is no leadership [4]. The leader can be an individual or in the leader's collective leadership in the form of a group of individuals [5]. Leadership is the relationship between individuals with one another, leaders must be able to influence others to be willing to cooperate in tasks related to achieving common goals [6]. In addition, Fitriani [7] defines leadership as the art of persuading subordinates to carry out tasks with confidence and enthusiasm. 
Leadership behavior is the specific actions of a person in directing and coordinating the work of group members [8]. The spirit of leadership is a character that must be possessed by every principal. The principal is the regulator of the development of a school institution. The principal must be responsible for the progress and decline of a school. The principal will prioritize public interests over personal interests.

The principal's job as a manager is to carry out management functions in order to mobilize existing resources, especially educators and education personnel to carry out the responsibilities or tasks that are shared (job description) with HRM and overcome these difficulties by themselves, before asking the principal for help [9]. The principal has the following roles and duties: Educator, Manager, Administrator, Innovator, Motivator, Supervisor, and Leader [10]. In the school organizational system, the principal is the leader of other school communities. Teachers, employees and students. As a leader, the behavior, and characteristics of the principal will influence the behavior of other school communities. Positive behavior from the principal will spur teachers and employees to provide positive behavior in achieving educational goals.

Job satisfaction is an individual thing because each individual will have a different level of satisfaction according to the values that apply to each individual. The level of perceived satisfaction is in accordance with the wishes of the individual. Job satisfaction is a general attitude towards a person's job that shows the difference between the number of rewards workers receive and the amount they believe they should receive [11]. Overall job satisfaction for an individual is the sum of job satisfaction (from each aspect of the job) multiplied by the degree of importance of that aspect of the individual's job. An individual will feel satisfied or dissatisfied with his work which is personal, which depends on how he perceives a match or contradiction between his desires and the results he gets (12). The determinants of job satisfaction include salary, working conditions and working relationships (superiors and colleagues) which are closely related to productivity, attendance (absenteeism), turnover, response to job dissatisfaction [13].

Teachers play an essential role in the teaching and learning process with students to have knowledge and skills in each subject area. Besides, teachers also have the responsibility of educating students to have good attitudes and behavior in the school and community environment [14]. The principal as the driving force, determinants of school policy direction, and determines how the goals of the school and education in the school he leads are to be realized, demanded the behavior and characteristics of the principal's duties in order to provide service and satisfaction to educators and education in the school being led.

The results of observations at SMA Negeri Mesuji Makmur were that there was dissatisfaction with the teaching and education staff over the leadership of the principal who was their superior. This can be seen from the lack of optimal leadership of the principal in carrying out duties at school, the principal has a behavior that does not respect the performance of educators and education. Factors that are thought to be the cause of the dissatisfaction of teachers and education staff with the performance of school principals. Other factors that are thought to be the cause of low satisfaction include the salaries received by employees that are not in accordance with the performance of teachers and education personnel, working in unpleasant room and school conditions. According to Yuk et al. [15], the variable satisfaction of subordinates for leadership is influenced by variables of leader behavior, task characteristics, environmental characteristics, and subordinate characteristics and the expectations and valence of subordinates for leadership.

\section{METHODS}

The research method used in this research is descriptive quantitative research, namely research that aims to describe or explain something as it is. This study wanted to determine the influence of behavioral factors or variables and the characteristics of the principal's duties on the satisfaction of teachers and education staff at SMA Negeri Mesuji Makmur with a sample of 56 respondents used questionairre. Data analysis used simple and multiple linear regression through SPSS version 25 for windows.

\section{RESULTS AND DISCUSSION}

Based on the first hypothesis test shown in Table 1, the analysis of the coefficient of determination using simple linear regression obtained an R-value of 0.936 . It means that the principal's behavior has a powerful effect on teachers and education staff's satisfaction, as evidenced by the correlation value between 0.800 1,000 which is in the very high category [16]. 
Table 1. The analysis of the coefficient of determination using simple linear regression

\begin{tabular}{clll}
\hline \multicolumn{3}{l}{ Model Summary } & \\
\hline R-value & R-Square & Adj. R-Square & Std. Error \\
$.936^{\mathrm{a}}$ & .877 & .875 & 4.642 \\
\hline
\end{tabular}

Based on Table 1, it can be seen that the coefficient of determination R Square (R2) is 0.877 , which means that the percentage of the principal's behavior can influence the satisfaction of teachers and education at Mesuji Makmur State High School of $87.70 \%$. In this study, the standard deviation is 4.642, where the smaller the standard deviation, the better the model [16]. Analysis of coefficient determination is to determine the percentage contribution of the effect of the independent variable on the dependent variable [16]

Table 2. The results of the hypothesis test the effect of principal's behavior on the satisfaction of teachers and education staff analysis

\begin{tabular}{|c|c|c|c|c|c|}
\hline \multicolumn{6}{|l|}{ Coefficients $^{\mathrm{a}}$} \\
\hline \multirow[b]{2}{*}{ Model } & $\begin{array}{l}\text { Unstanc } \\
\text { Coeffic }\end{array}$ & $\begin{array}{l}\text { ardized } \\
\text { ents }\end{array}$ & $\begin{array}{l}\text { Standardized } \\
\text { Coefficients }\end{array}$ & \multirow[b]{2}{*}{$\mathrm{t}$} & \multirow[b]{2}{*}{ Sig. } \\
\hline & $\mathrm{B}$ & $\begin{array}{l}\text { Std. } \\
\text { Error }\end{array}$ & Beta & & \\
\hline Principal's behavior & $\begin{array}{l}10.555 \\
.928\end{array}$ & $\begin{array}{l}6.750 \\
.047\end{array}$ & .936 & $\begin{array}{l}1.564 \\
19.607\end{array}$ & $\begin{array}{l}.124 \\
.000\end{array}$ \\
\hline
\end{tabular}

Table 2 is shown the constant-coefficient (Constant $)=10.555$ and the principal's behavior coefficient number is 0.928 , so that a simple linear regression equation is obtained $\hat{\mathrm{Y}}=10.555+0.928 \mathrm{X}$ or the partial regression equation between the variables $\mathrm{X} 1$ to $\mathrm{Y}$ is $=10.555+0.928 \mathrm{X} 1$. The coefficient analysis results obtained tcount is 19.607 and a p-value of $0.00<0.05$, which means that $\mathrm{H} 0$ is rejected and $\mathrm{Ha}$ is accepted. Thus it can be said that partially stated that there is a positive influence on the principal's behavior on the satisfaction of teachers and education at SMA Negeri Mesuji Makmur. Fraser [17] found that the satisfication of educators on supervisor depend on gender, or level of teaching, or years of teaching experience. So, supervisory behavior absolute make a significant and unique contribution to the prediction of one or more satisfaction indices.

Based on the second hypothesis test, the analysis of the coefficient of determination using simple linear regression based on the Model Summary output value in Table 3 , the $\mathrm{R}$ number is 0.936. It can be said that the characteristics of the principal's duties have a very strong effect on the satisfaction of teachers and education personnel at SMA Negeri Mesuji Makmur, as evidenced by the correlation value between $0.800-1,000$.

Table 3. The results of the coefficient determination of the effect characteristics of principal on the satisfaction of teachers and education staff

\begin{tabular}{|c|c|c|c|c|}
\hline \multicolumn{5}{|c|}{ Model Summary } \\
\hline Model & $\mathrm{R}$ & $\begin{array}{l}\text { R- } \\
\text { Square }\end{array}$ & $\begin{array}{l}\text { Adj. } \\
\text { Square }\end{array}$ & Std. Error \\
\hline & $.936^{\mathrm{a}}$ & .877 & .875 & 4.642 \\
\hline
\end{tabular}

Table 3 shows a standard Error of estimation (Standard Deviation) is 4.642 , and the coefficient of determination R-Square (R2) is 0.877 . It means that the percentage of the influence of the principal's duties' characteristics can contribute to the satisfaction of teaching staff and education in SMA Negeri Mesuji Makmur by $87.70 \%$.

Table 4. The results of the hypothesis test the effect of the Characteristics of principal on the satisfaction of teachers and education staff analysis

\begin{tabular}{|c|c|c|c|c|c|c|c|}
\hline \multicolumn{8}{|c|}{ Coefficients $^{\mathrm{a}}$} \\
\hline \multirow{3}{*}{\multicolumn{2}{|c|}{ Model }} & & \multirow{2}{*}{\multicolumn{2}{|c|}{$\begin{array}{l}\text { Unstandardized } \\
\text { Coefficients }\end{array}$}} & Standardized & \multirow[t]{3}{*}{$\mathrm{t}$} & \multirow[t]{3}{*}{ Sig. } \\
\hline & & & & & Coefficients & & \\
\hline & & & B & Std. Error & Beta & & \\
\hline & (Constant) & & 27.073 & 7.619 & & 3.553 & .001 \\
\hline 1 & $\begin{array}{l}\text { Characteristics } \\
\text { principal }\end{array}$ & of & .822 & .054 & .900 & 15.21 & .000 \\
\hline
\end{tabular}


Based on the second hypothesis in Table 4, the constant coefficient value is obtained (Constant) $=27.073$ and the coefficient of $\mathrm{X} 2=0.822$, so that the simple linear regression equation is obtained $\hat{Y}$ $=27.073+0.822 \mathrm{X} 2$. The coefficient analysis results obtained tcount of 15.206 and p-value of $0.00<0.05$, which means that $\mathrm{H} 0$ is rejected and $\mathrm{Ha}$ is accepted. That means that there is a positive influence on the characteristics of the principal's duties on teachers and education staff's satisfaction at SMA Negeri Mesuji Makmur.

Based on the third hypothesis test in Table 5 , multiple linear regression analysis results based on the Model Summary output obtained the R number of 0.940 . That means that the percentage of the influence of the behavior and characteristics of the principal's task can contribute a powerful influence on the satisfaction of teachers and education personnel at SMA Negeri Mesuji Makmur, because the multiple correlation value is between $0.800-0.1000$.
Table 5. The coefficient determination of the effect principal's behavior and Characteristics of principal on the satisfaction of teachers and education staff analysis

\begin{tabular}{|c|c|c|c|c|}
\hline \multicolumn{5}{|c|}{ Model Summary } \\
\hline \multirow[t]{2}{*}{ Model } & $\mathrm{R}$ & $\begin{array}{l}\text { R- } \\
\text { Square }\end{array}$ & $\begin{array}{l}\text { Adj. R- } \\
\text { Square }\end{array}$ & Std. Error \\
\hline & $.940^{\mathrm{a}}$ & .883 & .879 & 4.566 \\
\hline $\begin{array}{l}\text { a. Pre } \\
\text { Charact } \\
\text { and edu }\end{array}$ & $\begin{array}{l}\text { rs: } \\
\text { cs of pi } \\
\text { n staff }\end{array}$ & $\begin{array}{l}\text { nstant), } \\
\text { cipal, th }\end{array}$ & $\begin{array}{l}\text { principal's } \\
\text { e satisfaction }\end{array}$ & $\begin{array}{r}\text { behavior, } \\
\text { of teachers }\end{array}$ \\
\hline
\end{tabular}

Table 5 shows the standard deviation is 4.566, where the smaller the standard deviation, the better the model. The results of the coefficient of determination R Square (R2) is 0.883 , which means that the effect of the behavior and characteristics of the principal's duties together is able to contribute a very strong influence on the satisfaction of teachers and education in SMA Negeri Mesuji Makmur, namely $88.3 \%$. In comparison, the remaining $11.7 \%$ is affected by other factors not mentioned in this study.

Table 6. The results of the hypothesis test the effect of discipline and school culture on teacher performance analysis

\begin{tabular}{|c|c|c|c|c|c|}
\hline \multirow[b]{2}{*}{ Model } & \multicolumn{2}{|c|}{$\begin{array}{l}\text { Unstandardized } \\
\text { Coefficients }\end{array}$} & \multirow{2}{*}{$\begin{array}{l}\text { Standardized } \\
\text { Coefficients } \\
\text { Beta }\end{array}$} & \multirow[b]{2}{*}{$\mathrm{t}$} & \multirow[b]{2}{*}{ Sig. } \\
\hline & $\mathrm{B}$ & $\begin{array}{l}\text { Std. } \\
\text { Error }\end{array}$ & & & \\
\hline & 11.194 & 6.650 & & 1.683 & .098 \\
\hline Principal's behavior & .729 & .127 & .736 & 5.728 & .000 \\
\hline $\begin{array}{l}\text { Characteristics } \\
\text { principal }\end{array}$ & of .197 & .117 & .216 & 1.680 & .099 \\
\hline
\end{tabular}

The third hypothesis test using multiple linear regression coefficients, as shown in Table 6 , obtained the constant-coefficient (Constant) is 11,194. The simple regression coefficient of the effect of behavior on the satisfaction of teaching staff and education at SMA Negeri Mesuji Makmur is obtained of 0.729 . The simple regression coefficient of the effect of the characteristics of the principal's duties on the satisfaction of the teaching staff and education at SMA Negeri Mesuji Makmur obtained a value of 0.197 , and the multiple regression coefficient of the behavior and characteristics of the principal's duties partially on the satisfaction of teachers and education in SMA Negeri Mesuji Makmur Prosperous obtained a value of 11,194 . Based on the value obtained, the multiple linear regression coefficient $\mathrm{Y}=11.194+0.729 \mathrm{X} 1$ $+0.197 X 2$.
Table 6 shows the statistical value for the coefficient of the principal's behavior variable $(\mathrm{X} 1)$, namely $t_{\text {count }}=5.728$ and p-value is $0.00<0.05$ or $\mathrm{H} 0$ is rejected, that means the principal's behavior has a positive influence on the satisfaction of educators and education personnel at SMA Negeri Mesuji Makmur. The statistical value for the coefficient of the principal's task characteristics variable $(\mathrm{X} 2)$ is tcount is 1.680 and $\mathrm{p}$-value is $0.099 / 2=0.00<0.05$ or $\mathrm{H} 0$ is rejected, that means the principal's task characteristics have a positive effect on the satisfaction of teachers and education in SMA Negeri Mesuji Makmur. 
Table 7. The result of Multiple Linear Regression Analysis by Simultaneous

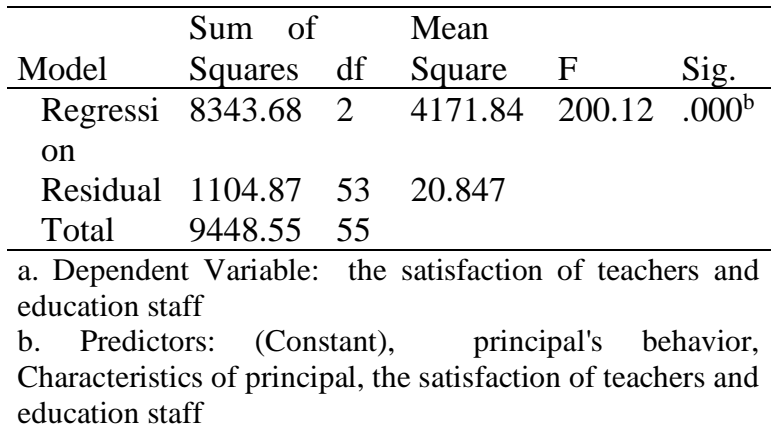

Based on the third hypothesis test using the F-test formula is shown in Table 7, showing the statistical value of Fcount $=200.120$ and $p$-value $0.000<0.05$. It means that $\mathrm{H} 0$ is rejected, which means that there is a linear influence on the behavior and characteristics of the principal's task on the satisfaction of teachers and education. This also means that there is an effect of the behavior and characteristics of the principal's duties together (simultaneously) on the satisfaction of teachers and education staff at SMA Negeri Mesuji Makmur.

\section{CONCLUSION}

This study concludes that there is an effect of the principal's behavior on educators' satisfaction and education in SMA Negeri Mesuji Makmur. The behavior of the principal has a very strong influence on the satisfaction of educators and educators, the magnitude of the influence is $87.7 \%$. There is an influence of the characteristics of the principal's duties on the satisfaction of educators and education in SMA Negeri Mesuji Makmur. The characteristics of the principal's duties give a very strong influence on the satisfaction of educators and education, the magnitude of that influence is $87.7 \%$. There is a simultaneous influence of the behavior and characteristics of the principal's duties on the satisfaction of educators and educators in SMA Negeri Mesuji Makmur. The behavior and characteristics of the principal's duties have a very strong influence simultaneously on the satisfaction of educators and educators, the magnitude of the influence is $83.3 \%$. In addition, the advice that can be given among them to the Principal, should always provide behavior and characteristics of tasks that can give satisfaction to educators and education both instruction, guidance, coaching for teachers as subordinates so that teachers work professionally and teacher performance can be even better. For educators and educators, they should always work professionally and responsibly, in order to show even better performance.

\section{REFERENCES}

[1] Mulyasa. 2011. Menjadi Guru Profesional Menciptakan Pembelajaran Kreatif dan Menyenangkan. Bandung: Remaja Rosdakarya.

[2] Kristiawan, Safitri, \& Lestari. 2017. Manajemen Pendidikan. Yogyakarta: Deepublish.

[3] Usman, A. (2016). Penanganan Pascapanen Jagung. dalam www.ipb.ac.id/ usmanahmad/Penangananj agung.htm diakses tanggal 6 mei 2020

[4] Wirawan, Sarwono, Sarlito. (2003). Psikologi Remaja. Jakarta: PT RajaGrafindo Persada

[5] Andriani, N. (2018). Hubungan Bentuk Prilaku Bullying Dengan Tingkat Stres Pada Remaja Korban Bullying. Universitas Riau

[6] Thoha, M. (2004). Perilaku Organisasi, Konsep Dasar dan Aplikasinya. Jakarta: Raja Grafindo Persada.

[7] Fitriani, Herry, Lian. (2020). Pengaruh Kepemimpinan Kepala Sekolah dan Komitmen Guru terhadap Kinerja Profesional Guru. Diterbitkan dalam Jurnal Pendidikan Tambusai. SSN: 2614-6754 (print) ISSN: 2614-3097(online) Halaman 1658-1666 Volume 4 Nomor 2 Tahun 2020. Palembang: Universitas PGRI Palembang diakses tanggal 6 mei 2020

[8] Mulyadi. (2010). Kepemimpinan Kepala Sekolah Dalam Mengembangkan Budya Mutu. Malang : UIN Maliki Press

[9] Hendarman dan Rohanim. (2018). Kepala Sekolah Sebagai Manajer Teori dan Praktik. Bandung: Remaja Rosdakarya.

[10] Mulyasa. (2004). Menjadi Kepala Selolah Profesional dalam Konteks Menyukseskan $M B S$ dan KBK, Bandung: Remaja Rosdakarya

[11] Robbins S P. (2003). Perilaku Organisasi. Jakarta : PT. Indeks.

[12] Gomes, F. Cardoso, (2005). Manajemen Sumber Daya Manusia, Jakarta: Gunung Agung

[13] Yandra, G. (2011). Kepuasaan Kerja Pegawai. Online https://yandragautama.wordpress.com/2011 /12/27/kepuasan-kerja-pegawai/ diakses tanggal 20 April 2020

[14] Heri. (2019). pengertian guru: definisi, tugas dan peran guru dalam pendidikan. Online https://salamadian.com/pengertianguru/ diakses tanggal 6 Mei 2020

[15] Yuk, G dan Wexley, Kenneth N. (2005). Perilaku Organisasi dan Psikologi Personalia. Jakarta: PT Rineka Cipta

[16] Arikunto, S. (2010). Prosedur Penelitian 
Suatu Pendekatan Praktek. Edisi Revisi. Jakarta: Rineka Cipta.

[17] Fraser, K.P. (1980), "Supervisory Behavior and Teacher Satisfaction", Journal of Educational Administration, Vol. 18 No. 2, Pp.

224-

231. Https://Doi.Org/10.1108/Eb009828 